\title{
Awareness Regarding Better Business Bureaus and Chambers of Commerce among College Students: Should It Be a Concern for Business Schools?
}

\author{
Susan M. L. Zee ${ }^{1}$, Avinash Waikar ${ }^{*}$, Lillian Yee-Man Fok ${ }^{2}$ and Kenneth J. Lacho² \\ ${ }^{1}$ Department of Marketing and Supply Chain Management, Southeastern Louisiana University \\ United States \\ ${ }^{2}$ Department of Management, University of New Orleans, United States \\ Email: avinash.waikar@selu.edu
}

\begin{abstract}
This study examines the awareness of college students regarding the roles and functions of Better Business Bureaus (BBB) and chambers of commerce (CC). The study shows that the overall awareness/knowledge of both $\mathrm{BBB}$ and chambers of commerce was low for all students, even lower than the knowledge of the public at large. The study shows a significant positive correlation between the average score regarding awareness of $\mathrm{BBB}$ and that of chambers of commerce which suggests students who have a higher level of awareness of BBB would have higher level of awareness of chambers of commerce. There was a statistically significant difference in the level of awareness according to working experience and race, but there was little difference in terms of gender.
\end{abstract}

Keywords: Better business bureaus, chambers of commerce, small businesses

\section{Introduction}

There are many sources of help or information available to the start-up or existing small business owners. Trade associations, Service Corps of Retired Executives (SCORE), the U.S. Small Business Administration (SBA), Small Business Development Centers (SBDC), state or local economic development agencies, and Dun \& Bradstreet are among the several sources of help. Other helpful organizations are the local Chamber of Commerce and the area Better Business Bureau. The chamber can help the small business owner promote his/her small business. For example, the chamber can help by holding networking events such as breakfasts, luncheons, After Hours, speed dating, and committee work. Chamber members may sponsor events, hold a ribbon-cutting for a grand opening and advertise over the chamber website (Lacho \& Brockmann, 2011). In addition, the chamber may help the small business owner improve his/her business skills by offering seminars and workshops (Brockmann \& Lacho, 2015).

The Better Business Bureau (BBB) provides a sense of trust and security to users of its services, either consumers or businesses. BBB services include dispute arbitration and as a source of getting information about a prospective customer or supplier (Fok, Lacho, \& Mitchell, 2013).

Studies by Fok, Lacho \& Brockmann (2013) and Fok, Lacho, \& Zee (2015) found that college students had a weak knowledge of chambers of commerce. Similarly, a study by Fok, Lacho, \& Mitchell (2013) found that college students had little knowledge of BBB. This has important implication since these students will be working for a business or start their own business. In essence, this should be a concern for business schools since BBB and Chamber of Commerce can be useful and important resources that can help you succeed in the competitive business world.

An example of the lack of student knowledge of helpful sources is illustrated by the following example. One of the authors chaired a panel of persons who have provided financial assistance to small business start-ups or owners. The panel was sponsored by the Student Finance and Economic Association on a college campus. Surprisingly, none of the 20 students in attendance had any knowledge about SCORE. It was also unclear as to how much they know about local BBB and local chamber of commerce. Thus, the purpose of this paper is to explore the association between students' awareness and knowledge of $\mathrm{BBB}$ and that of chambers of commerce. 


\section{$2 \quad$ Literature Review}

The Better Business Bureau is a non-profit organization that provides services to consumers and businesses alike. A 2007 survey by the Princeton Survey Research Associates International showed that $89 \%$ of principal owners and top managers of member and non-member U.S. businesses said they had heard or read something about the BBB (Princeton, 2007). Even more surprising is the finding that specific knowledge about the functions and roles of $\mathrm{BBB}$ and its activities is lower than what might be expected. Only the most basic of BBB service areas are commonly known to business leaders overall, taking and processing consumer complaints (78\%), and providing consumers with pre-purchase information about companies (Princeton, 2007). The same Princeton Study measured the public's knowledge of the BBB. It was found that 74 percent of the U.S. public cannot identify what type of organization the BBB is.

Despite the important role of BBB's in the U.S. economy, there have been few studies on them. Young (1994) found that $81 \%$ of BBB members surveyed used the BBB to check the reliability of unknown companies before doing business with them. Some $68 \%$ belong to the BBB because the BBB warned customers of scams (Young, 1994).

The findings of a survey conducted by Princeton Survey Research Associates International found that seven in ten consumers indicated that knowing that a firm is a BBB accredited business made them more likely to do business with it (Princeton Survey Research, 2007). In addition, Lacho and Mitchell (2010) described how a BBB Accredited member small business owner could use the services of the Bureau to benefit the firm and contribute to its profitability.

A study by Fok, Lacho, \& Mitchell (2012) found that higher level college students had a significantly higher level of knowledge about the BBB. Perhaps experience has led to a higher level of BBB knowledge. At any rate, regardless of work or academic experience, student knowledge of the BBB is low overall. A study by Fok, Lacho, and Mitchell (2013) found that business students at The University of New Orleans (UNO) have little knowledge of the BBB and its services. Another study by Zee, Fok, and Lacho (2015) examined knowledge of the BBB by business school students in two universities in the south. Further study by Fok, Lacho \& Zee (2016) showed that the overall knowledge of Chambers of Commerce of business students in two universities was low. There was a statistically significant difference on their average score for the two universities with the university in the rural area scoring higher. There was little difference in the level of knowledge according to sex, age or work experience.

Chambers of commerce is also an important force in any community, urban or rural, large or small. Yet, little academic research has been done on them. Lacho (2008) studied the government affairs activities of chambers of commerce in suburban New Orleans. Each of the studied chambers has a standing government affairs or public committee which monitors local, state and federal issues and informs the membership about them. Members have the opportunity to interact with local, state, and nationally elected officers at locally-based forums such as luncheons or meet them at the state legislature. Lacho and Brockmann (2011) studied how a small business could be promoted through the services of a chamber of commerce. Their study of a single chamber showed that online listings are used. There are many opportunities for networking, e.g., at luncheons or special networking events. A 2012 study by Lacho and Brockmann examined the educational services provided by a chamber to help small business owners improve their business skills. One service was the traditional lecture/workshop setting followed by a passive educational setting such as a luncheon speaker. Lastly, networking events offered knowledge transfer opportunities.

The study by Brockmann and Lacho (2012) also compared how small chambers in rural areas and large urban-based chambers provided help to promote small businesses and to provide educational services. It was found that rural-based chambers have different priorities than large chambers. Small chambers focus on the community first, then business. A study by Fok, Lacho, and Brockmann (2013) found that college students had little knowledge of chambers of commerce. Finally, Lacho, Fok, and Zee (2015) examined knowledge of chambers of commerce by business school students in a rural setting versus in an urban setting.

The purpose of this study is to examine the relationship between the awareness/knowledge of college business students about the Better Business Bureau and chambers of commerce (CC). (See Research Question 1) Specifically, we have speculated that there may be overall differences in the knowledge of 
the $\mathrm{BBB}$ and that of chambers of commerce between male and female students and between working and non-working students. (See Research Questions 2 and 3). We also investigate whether there is difference in the knowledge of the BBB and that of chambers of commerce between white and not-white students (See Research Question 4).

Research Question 1: There will be no correlation between BBB knowledge scores and CC knowledge scores.

Research Question 2: There will be no differences in BBB knowledge scores and CC knowledge scores between male and female students.

Research Question 3: There will be no differences in BBB knowledge scores and CC knowledge scores between students working full-time or part-time and students not working.

Research Question 4: There will be no differences in BBB knowledge scores and CC knowledge scores between white and not-white students.

\section{$3 \quad$ Method}

\subsection{Subjects}

Subjects in the sample were students from four-year public university in the South. There were approximately 191 students roughly $50 \%$ female and $50 \%$ male with $61 \%$ in the $18-22$ age group, $20 \%$ in the $23-27$ age group, and $12 \%$ in the $28-35$ age group. $82 \%$ of these students were working full-time or part-time. $33 \%$ of the students were taking 3 to 4 courses, and $60 \%$ taking 5 to 6 courses. The university student population consisted of $72 \%$ Caucasian students.

\subsection{Data}

In this study, we assessed awareness and the knowledge of college business students about the BBB with a series of 32 statements requiring a true/false response. These statements involve the BBB's governance and functions/services. The knowledge of chambers was measured using a series of 24 statements on a true/false scale. These statements also included topics such as the chambers' governance, functions, and services.

\section{$4 \quad$ Results}

Table 1 summarizes the statements about the BBB's governance, operations, and functions/services that received correct percentages above $70 \%$. Only two statements scored higher than $90 \%$, which are "BBB business reports are available 24 hours a day 7 days a week on the local BBB website." and "The BBB's only job is to process complaints." The statement "Angie's List" provides comments on businesses" has 88.5\% answering correctly. "The BBB assists consumers and businesses in resolving disputes that result from customer complaints" and "The services of the BBBs are for the use by consumer customers only. BBB services are not available to owners of small businesses" have roughly $87 \%$ answered correctly. Table 1 also lists other five statements which have correct percentages from $70 \%$ to $76 \%$.

Table 2 summarizes the statements about the BBB's governance, operations, and functions/services that received correct percentages below $50 \%$. The two biggest misconceptions are "There is at least one BBB office in all 50 states" and "There is no difference between being an accredited BBB business member and simply having a good rating." Only $11.5 \%$ of the students responded correctly to those two statements. The statement "The New Orleans BBB provides excellent opportunities for person-to-person networking" has $22.5 \%$ answered correctly. "BBB board members are paid a fee to serve on a local BBB board of directors" has roughly 37.7\% answered correctly. Approximately 41.4 percent answered "The BBB accepts verbal complaints" correctly. "The BBB is a local government agency" has $41.9 \%$ being answered correctly. Table 2 also lists another three statements which have correct percentages from $45 \%$ to $48 \%$. 
Table 1. BBB statements with the ten highest correct percent responses

\begin{tabular}{lcc}
\hline \multicolumn{1}{c}{ Statement } & Answer & Percentage \\
\hline 1. BBB business reports are available 24 hours, 7 days a week on local BBB website. & False & 93.7 \\
2. BBB's are required to report on government actions against local businesses. & True & 75.9 \\
3. BBB reports are available on Facebook. & False & 71.2 \\
4. "Angie's List" provides comments on businesses. & True & 88.5 \\
5. The BBB's only job is to process complaints. & False & 92.7 \\
6. The BBB assists consumers and businesses in resolving disputes that result from & True & 87.4 \\
consumer complaints. & True & 71.2 \\
7. The BBB charges the consumer a fee to handle a complaint. & False & 70.0 \\
8. BBB charges consumers for BBB business reports. & False & 75.4 \\
9. The BBB does not alert the public about businesses that treat consumers unfairly. & False & 86.9 \\
10. The services of the BBB are for the use by consumer customers only. BBB & & \\
services are not available to owners of small businesses. & \\
\hline
\end{tabular}

Table 2. BBB statements with the nine lowest correct percent responses

\begin{tabular}{lcc}
\hline \multicolumn{1}{c}{ Statement } & Answer & Percentage \\
\hline 1. The BBB is local government agency & False & 41.9 \\
2. There is at least one BBB office in all 50 states & False & 11.5 \\
3. BBB board members are paid a fee to serve on a local BBB board of directors. & False & 37.7 \\
$\begin{array}{l}\text { 4. The New Orleans BBB provides excellent opportunities for person-to-person } \\
\text { networking. }\end{array}$ & False & 22.5 \\
5. The BBB accepts verbal complaints & False & 41.4 \\
6. A company can ignore consumer complaints from the BBB. & True & 47.6 \\
7. BBB accredited businesses are guaranteed a higher grade than non-accredited & False & 44.5 \\
businesses. & True & 11.5 \\
8. There is no difference between being an accredited business member and simply & \\
having a good rating. & False \\
9. Sally Hunter is looking for an air conditioning service. She contacts the BBB. The & 47.6 \\
BBB will recommend an air conditioning service to her. & \\
\hline
\end{tabular}

Table 3. Chambers of Commerce statements with the ten highest correct percent responses

\begin{tabular}{lcc}
\hline \multicolumn{1}{c}{ Statements } & Answer & Percentage \\
\hline 1. Chambers of commerce have existed in the United States since the middle 1800s. & True & 77.0 \\
2. Chambers support economic development initiatives in their area. & True & 93.7 \\
3. Chambers exist only in big cities and not small towns. & False & 91.1 \\
4. Chambers members come from both large (more than 50 employees) and small & True & 90.6 \\
(fewer than 50 employees) companies. & False & 86.4 \\
$\begin{array}{l}\text { 5. Chambers are an advocacy voice for only large companies to public officials } \\
\text { 6. Chambers membership is for "for-profit" businesses only. Not-for-profit }\end{array}$ & False & 81.2 \\
organizations are not permitted to be chamber members. & False & 71.2 \\
7. Chambers provide loans t chamber members. & True & 93.7 \\
8. Chambers provide presentations and workshops to improve members' business & True & 98.4 \\
skills. & True & 93.7 \\
9. Chambers provide networking opportunities for small business owners. & 10. Chambers are an advocacy voice to public officials especially for small business.
\end{tabular}

Table 3 summarizes the statements about the chamber's governance, operations, and functions/services that received the highest scores from students at the university. The statement "Chambers provide networking opportunities for small business owners" has answered $98.4 \%$ correctly. 
Three statements received $93.7 \%$ correct scores are "Chambers are an advocacy voice to public officials especially for small business", "Chambers provide presentations and workshops to improve members' business skills", and "Chambers support economic development initiatives in their area." The statements "Chambers exist only in big cities and not small towns" and "Chambers members come from both large (more than 50 employees) and small (fewer than 50 employees) companies" have roughly $91 \%$ answered correctly. Only two statements score $80 \%$ and above and two statements score $70 \%$ and above.

Table 4 summarizes the statements about the chamber's governance, operations, and functions/services that received the lowest scores from students at the university. The biggest misconception is "There are roughly 5,000 chambers of commerce in the United States today." Only $18.8 \%$ of the students answered this correctly. The next is "Ms. Sally Hunter is looking for an accountant. She contacts the local chamber of commerce. The chamber will recommend an accountant to her" with $27.7 \%$ answering correctly. The statement "Chambers of Commerce are funded by local government" has $30.4 \%$ answering correctly. Forty percent of the students answered "Chambers are not allowed to influence governmental regulations at the federal level" correctly. "Chambers of commerce are local government agencies" has roughly $45.3 \%$ answered correctly. About $48.7 \%$ answered "Chambers may endorse a person running for a local political office" correctly.

Table 4. Chambers of commerce statements with the six lowest correct percent responses

\begin{tabular}{lcc}
\hline \multicolumn{1}{c}{ Statement } & Answer & Percentage \\
\hline 1. Chambers of commerce are local government agencies. & False & 45.3 \\
2. Chambers are not allowed to influence governmental regulations at the federal level. & False & 40.0 \\
3. Chambers of commerce are funded by the local government & False & 30.4 \\
4. There are roughly 5,000 chambers of commerce in the United States today. & False & 18.8 \\
5. Chambers may endorse a person running for a local political office. & False & 48.7 \\
6. Ms. Sally Hunter is looking for an accountant. She contacts the local chamber of & False & 27.7 \\
commerce. The chamber will recommend an accountant to her. & & \\
\hline
\end{tabular}

The first research question investigated whether there would be a correlation between BBB knowledge scores and CC knowledge scores. The results are summarized in Table 5. The correlation is statistically significant at the 0.01 level. The correlation coefficient is 0.266 . Although this is not very high, we can conclude that the students who scored higher on BBB statements would likely have higher level of knowledge about chambers of commerce.

Table 5. Pearson correlation between BBB knowledge scores and CC knowledge scores

\begin{tabular}{llcc}
\hline & & $\begin{array}{c}\text { Score of Chambers } \\
\text { Knowledge }\end{array}$ & $\begin{array}{c}\text { Score of Better Business Bureau } \\
\text { Knowledge }\end{array}$ \\
\hline Score of Chambers & Pearson Correlation & 1 & $.266^{* *}$ \\
Knowledge & Sig. (2-tailed) & 188 & .000 \\
& $\mathrm{~N}$ & & 187 \\
Score of Better Business & Pearson Correlation & $.266^{* *}$ & 1 \\
Bureau Knowledge & Sig. (2-tailed) & .000 & 190 \\
& $\mathrm{~N}$ & 187 & \\
$* *$. Correlation is significant at the 0.01 level (2-tailed). & & \\
\hline
\end{tabular}

Our second research question considered the possibility that male and female students have different levels of BBB knowledge and CC knowledge. MANOVA was used to test if the overall scores are different between male and female students. The MANOVA results were not statistically significant. This implies that male and female students seem to have roughly the same level of knowledge of BBB and that of the chambers of commerce. Both male and female students scored about 18.9 (59\%) out of 32 questions correctly in BBB knowledge. On average, both male and female students scored approximately 15.6 (65\%) out of 24 questions correctly in CC knowledge. 
Our third research question examined whether there would be differences in BBB knowledge and CC knowledge between students working and students not working. MANOVA was used and the results are not significant. This implies that regardless of their working status, students seem to have roughly the same level of BBB knowledge as that of CC knowledge. On average, students working full-time or parttime scored 19.1 out of 32 questions correctly and students who were not working scored 17.8 out of 32 questions correctly in BBB knowledge. Students working full time or part-time had an average of 15.7 out of 24 correctly and the students who were not working scored 15.5 out of 24 correctly in CC knowledge.

The fourth research question stated that there would be no differences in BBB knowledge scores and CC knowledge scores between white and not-white students. The results of MANOVA are statistically significant at the level of 0.1. The overall score of CC knowledge is not significant; however, the overall score of BBB knowledge is significant at the 0.05 level. On average, both white students and not-white students scored about $16(67 \%)$ out of 24 questions correctly in CC knowledge. White students scored $19.2(60 \%)$ out of 32 questions correctly and not-white students scored $17.8(56 \%)$ out of 32 questions correctly in BBB knowledge. This result suggests that white students have higher level of knowledge in BBB than not-white students.

Another test compared full-time students with part-time students. The MANOVA result is significant at the level of 0.051, but the overall scores of both BBB and CC are not statistically significant. The part-time students' average score (19.4 out of 32) is slightly higher than full-time students (18.6 out of 32 ) in BBB knowledge. The part-time students answered 15.2 out of 24 questions correctly and the fulltime students answered 15.9 out of 24 questions correctly.

In synopsis, there were lack of awareness and misconceptions among the student populations regarding functions and operations of $\mathrm{BBB}$ and $\mathrm{COC}$. The two biggest misconceptions were "There is at least one BBB office in all 50 states" and "There is no difference between being an accredited BBB business member and simply having a good rating." The biggest misconception regarding CCC was "There are roughly 5,000 chambers of commerce in the United States today." The next was "Ms. Sally Hunter is looking for an accountant. She contacts the local chamber of commerce. The chamber will recommend an accountant to her". Finally, "Chambers of Commerce is funded by local government" was also a misconception.

\section{Discussion}

The purpose of this study is to examine the relationship between the knowledge of college business students about the Better Business Bureau and chambers of commerce. The study results show that there is a positive correlation between students' knowledge of BBB and that of chambers of commerce. This suggests that the students who have higher level of BBB knowledge would have higher level of knowledge in chambers of commerce.

The study results also show that working students have a significantly higher knowledge of the BBB than non-working students. It also confirms the findings of other researchers mentioned earlier that higher level college students had a significantly higher level of knowledge about the BBB. Perhaps experience has led to a higher level of BBB knowledge. At any rate, regardless of work or academic experience, student knowledge of the BBB is low overall.

The findings of this study suggest that students have less knowledge of the BBB than the public at large, about 26\%. It agrees with the Princeton Study that measured the public's knowledge of the Better Business Bureau's. It was found that 74 percent of the U.S. public cannot identify what type of organization the BBB is, only $26 \%$ can. It also agrees with the findings of other researchers Fok, Lacho and Mitchell mentioned earlier.

It was found that student awareness and knowledge of chambers of commerce were also weak. The findings agree with the results of other studies mentioned earlier. In this study, it was found that in terms of the level of education stages students further along in their college studies have a little higher level of knowledge of chambers of commerce.

The college student of today is the business and community leader of tomorrow. An important issue facing the BBB is how to get its message across to college students, perhaps anyone 18-30 years of age. Also known as Millennials, they represent the new face of the population in the United States. Assume 
that the higher level college student, 20-22 years of age in the business school is the target market for the BBB. How does the BBB reach them?

An initial step is to identify a business school professor who is active in the local business community. Perhaps the business school could appoint him/her as a liaison with the community.

A traditional way to reach students is to have BBB personnel speak to classes. Internships with the $\mathrm{BBB}$ or $\mathrm{BBB}$ member firms may be offered to students or selecting a young BBB employee and having him/her take part in school events. A student event may be sponsored by the BBB or BBB members. In addition, scams are an issue today. A "scam day" on the campus may be offered involving Better Business Bureau and Chambers of Commerce education, perhaps being sponsored by a student group or association. Last, a well-done website is a must.

The findings of this study suggest that student respondents have a low knowledge of chambers of commerce which is in agreement with the findings of some of the previous researchers. What is disturbing is that a large percentage of students had misconceptions about some of the basic aspects of a chamber. These aspects include the perception that the chamber is funded by local government, will recommend a business service provider, endorse a political candidate, and that chambers are local government agencies. Our study also found similar lower awareness and lack of knowledge about the Better Business Bureaus among the college students.

How do we improve student knowledge about chambers of commerce? One potential approach would be to encourage faculty members teaching introductory business courses and small business-related courses to include coverage of chambers of commerce. Guest speakers from local chambers could be invited to speak to students.

Universities have a large number of faculty committees. Smaller business schools such as at University of New Orleans (UNO) or Southeastern Louisiana University could set up a chamber-relations committee. The purpose of the committee would be to coordinate activities between the College of Business and area chambers of commerce. In New Orleans, the chamber committee could work with area chambers. These include Chambers in New Orleans, Jefferson, West St. Tammany, East St. Tammany, and other River Parishes Chambers of Commerce. Niche chambers include the Black, Asian, and Hispanic Chambers of Commerce. A similar committee at Southeastern University could coordinate with the Hammond Chamber of Commerce and the chamber at the nearby city of Ponchatoula.

The College of Business committee should be headed by a professor who is externally-oriented, e.g., a chamber member and/or takes part in the activities of other local business groups such as the American Marketing Association. Such a person would have the contacts to procure chamber speakers and arrange to have students take part in chamber's committees and activities. Such activities could include helping with special events such as the Jefferson Chamber Crawfish Boil or the annual Small Business Champions luncheon. Students could also be invited to chambers networking events.

This study suggests areas for future research about student knowledge about chambers of commerce. Perhaps a more interesting and needed area of research is the development of models of how universities and chambers can work together to educate students about chambers, as well as how they function and serve their community.

\section{Conclusion}

We can conclude that the student awareness and knowledge about the BBB organizations is weak. Working students seemed to have better awareness and knowledge of the BBB than non-working students. Overall, students at an urban university have a better knowledge of the BBB than those going to college in a rural area. There are a number of ways the BBB may reach college students. These range from traditional classroom lectures to taking part in special events.

The awareness and knowledge of chambers of commerce by college students also appears to be generally weak. In terms of the education level, the students further along in their college studies have a better knowledge of chambers. However, this college age student group needs to be made more aware of the local chambers and their benefits to small business owners.

Thus, awareness of and knowledge about BBB and Chambers of Commerce among business school students should be a concern to Business Schools. Perhaps a needed area of research is an examination of models of how universities and chambers can work together to give a more practical business 
education to students involving opportunities. Disciplines other than business such as liberal arts, engineering, and science could be included with work with chambers, but that is an issue to be addressed in another paper. The limitation of this study is the use of simple dichotomous questions for collecting data for correlational analysis. We would like to encourage researchers to use a rating scale or a Likert scale rather than a simple dichotomous questions approach that was used in this study in collecting the data.

\section{References}

1. E. N. Brockmann and K. J. Lacho, "Benefits of chamber of commerce membership: large versus small population centers," Paper presented at the Allied Academies International Conference, 2012.

2. E. N. Brockmann and K. J. Lacho, "Strategic planning: a practical primer for not-for-profit organizations," Proceedings of the Academy of Entrepreneurship, Allied Academies International Conference, Vol. 21, No. 1, pp.4-10.

3. Council of Better Business Bureaus, Arbitration Binding, Arlington: VA. Council of Better Business Bureaus, 2003.

4. L. Y. Fok, K. J. Lacho, and E. N. Brockmann, "College student knowledge of chambers of commerce," Business Journal for Entrepreneurs, Vol. 2013, No. 3, p.50, 2013.

5. L. Y. Fok, K. J. Lacho, and R. Mitchell, "College student knowledge of the Better Business Bureau," Business Studies Journal, Vol. 16, No. 1, pp. 57-62, 2013.

6. L. Y. Fok, K. J. Lacho, and R. Mitchell, "College student knowledge of the Better Business Bureau," Proceedings of the Business Studies Academy, Allied Academies International Conference, Vol. 4, No. 1, pp. 2933, 2012.

7. L. Y. Fok, K. J. Lacho, and S. Zee, "College student knowledge of chambers of commerce: a further look," Leadership and Organizational Management Journal, Vol. 2015, No.1, 2015.

8. L. Y. Fok, K. J. Lacho, and S. Zee, "Student knowledge of Better Business Bureaus and chambers of commerce," Leadership and Organizational Management Journal, Vol. 2016, No. 2, 2016.

9. S. Keeter and P. Taylor, The Millennials, Pew Research Center, Available: http://www.pewresearch.org/2009/12/10/the-milleannials

10.K. J. Lacho, "Government affairs activities of chambers of commerce," Paper presented at the Allied Academies International Conference, 2008.

11.K. J. Lacho and E. N. Brockmann, "Promoting a small business through the services of a chamber of commerce: One chamber's story," Entrepreneurial Executive, Vol. 16, pp. 1-8, 2011.

12.K. J. Lacho and E. N. Brockmann, "Improving the business skills of the small business owner through the educational services of a chamber of commerce: One chamber's story," Proceedings of the Academy of Entrepreneurship, Allied Academies International Conference, Vol. 18, No. 1, pp. 55-60, 2012.

13.K. J. Lacho, L. Y. Fok, and S. Zee, "Student knowledge of chambers of commerce: a comparison of two universities," Business Journal for Entrepreneurs, Vol. 2015, No. 2, 2015.

14.K. J. Lacho and R. Mitchell, "How a Better Business Bureau (BBB) can help BBB accredited small business members," Proceedings of the Academy of Entrepreneurship, Allied Academies International Conference, Vol. 16, No. 1, pp. 13-17, 2010.

15.L. Petrecca, "Tweet dreams of a booming business," USA TODAY, p. 3B, 2012.

16.Princeton Survey Research Associates International, "The Better Business Bureau's accreditation survey of consumers: A summary of major findings," Council of Better Business Bureaus, 2007.

17.M. Young, "The Better Business Bureau: A neglected tool toward developing quality management," Proceedings of the 18 National Small BusinessConsulting Conference, Small Business Institute Directors' Association, pp. 71$75,1994$.

18.S. Zee, L. Y. Fok, and K. J. Lacho, "Student Knowledge of the Better Business Bureau: a comparison of two universities," Leadership and Organizational Management Journal, Vol. 2015, No.4, pp. 24-31, 2015. 